\title{
TANAH PEKULEN DALAM STRUKTUR HUKUM AGRARIA DI JAWA
}

\author{
Widhiana H. Pư̂́idan Sulastriyono ${ }^{* *}$ \\ Sekolah Tinggi Pertanahan Nasional \\ Jalan Tata Bumi Nomor 5 Banyuraden Gamping, Sleman, Yogyakarta 55293 \\ Departemen Hukum Adat, Fakultas Hukum Universitas Gadjah Mada,Yogyakarta \\ Jalan Sosio Yustisia Nomor 1 Bulaksumur, Sleman DI Yogyakarta 55281
}

\section{Abstract}

The assigned of UUPA as national agrarian law has not ended the legal dualism land in Indonesia. Various opportunity or legal vacumm still be met especially in arrangement of land right based on customary law. This article want to know how is pekulen land positions in the structure of agrarian laws in Java? The analysis in this paper are based on the normative assessment. This paper found that pekulen land derived from customary law to be converted into the right of ownership or rights of use. However the conversion of rotating pekulen rights must be based on the original characteristics that are communal. This communal character needs legitimacy and further arrangements given the limited of existing land law.

Keywords: agrarian law, pekulen land, costumary law.

\section{Intisari}

Ditetapkannya UUPA sebagai hukum agraria nasional belum mengakhiri dualisme hukum tanah di Indonesia. Berbagai peluang atau kekosongan hukum masih ditemui terutama dalam kaitannya pengaturan hak atas tanah yang berdasar pada hukum adat. Artikel ini bermaksud untuk mengetahui bagaimana kedudukan tanah pekulen dalam struktur hukum agraria di Jawa? Analisis dalam tulisan ini didasarkan pada kajian normatif. Kesimpulannya tanah pekulen yang bersumber dari hukum adat haruslah dikonversi menjadi hak atas tanah menurut UUPA yaitu hak milik atau hak pakai. Meskipun demikian konversi hak pekulen bergilir harus didasarkan pada karakteristik asli hak pekulen yang bersifat komunal. Watak komunal ini memerlukan legitimasi dan pengaturan lebih lanjut mengingat masih terbatasnya ketentuan hukum yang ada.

Kata Kunci: hukum agraria, tanah pekulen, hukum adat.

\section{Pokok Muatan}

A. Pendahuluan 467

B. Pembahasan 468

1. Pengertian Tanah Pekulen dan Persebarannya 468

2. Sejarah Penguasaan Tanah Pekulen dan Dinamika Masyarakat 470

3. Sejarah Penguasaan Tanah Pekulen dan Dinamika Masyarakat 472

C. Penutup 479

\footnotetext{
Alamat korespondensi: widhianapuri@yahoo.com.

** Alamat korespondensi: sulastriyono@mail.ugm.ac.id.
} 


\section{A. Pendahuluan}

Hukum adat sebagai hukum yang bersumber dari masyarakat Indonesia menjadi jiwa dan ruh dalam pengaturan Agraria di Indonesia. Undangundang Nomor 5 Tahun 1960 tentang Peraturan Dasar Pokok-Pokok Agraria selanjutnya disebut UUPA, secara jelas menyebutkan hukum agraria Indonesia berdasar hukum adat yang bersifat komunalistik religius. Hukum tanah adat yang murni berkonsepsi komunalistik, yang mewujudkan semangat gotong-royong dan kekeluargaan yang diliputi suasana religius. ${ }^{1}$ Konsep komunalistik religius memungkinkan penguasaan bagian tanah bersama sebagai anugerah Tuhan Yang Maha Esa dengan hak yang bersifat perorangan atas tanah. Dapat dikatakan bahwa hak individual terdapat pada sebagian tanah bersama yang mengalami penguatan seiring perkembangan jaman.

Keberadaan hukum adat dengan konsep "komunal" dan "individual" atas tanah masih hidup lestari dalam wilayah Indonesia. Sering dijumpai berbagai peraturan terkait penguasaan tanah yang berbasis hukum adat, seperti tanah gogolan, tanah pekulen, tanah yasan, dan sebagainya. Nilai-nilai komunalistik yang menjadi karakter tanah adat masih kuat dirasakan bahkan ditengah semakin individualisnya penguasaan tanah dalam UUPA yang beraspek perdata, contohnya tanah pekulen. Tanah pekulen berkembang di Jawa khususnya Karesidenan Kedu termasuk di Desa Ngandagan Kab. Purworejo. ${ }^{2}$ Daya tariknya adalah terbentuknya struktur agraria baru akibat kebijakan yang diambil oleh Kepala Desa di tahun 19471964 yang bernama Soemotirto dengan tujuan pemerataan dan keadilan. Kebijakan ini berawal dari sawah komunal milik desa yang dipecahpecah dalam unit kulian masing-masing seluas 300 (tiga ratus) ubin dengan 1 ubin sama dengan 14 $\mathrm{m}^{2}$ pada masa pemerintahan Belanda dalam rangka memenuhi kebutuhan komoditas pertanian dan membagi beban wajib pajak. ${ }^{3}$ Pemecahan sawah komunal desa ini menghasilkan tanah pekulen yang tersebar di Pulau Jawa khususnya Jawa Timur dan Jawa Tengah. Tanah pekulen adalah sawah komunal desa yang pemanfaatannya dibagi-bagi kepada sejumlah petani penduduk inti baik secara tetap maupun secara giliran berkala. ${ }^{4}$ Penyebutan milik desa di sini bukan dalam arti sebagai pemilik sesuai ketentuan yuridis, namun lebih pada otoritas yang memiliki kuasa untuk mengatur dan menentukan alokasi penggarap atas tanah sawah tersebut. Pemegang kuasa atas tanah ini disebut kulian atau kuli baku. Keistimewaan Desa Ngandaganyaitu karena ada sifat bergilir di atas tanah pekulen tetap. Setiap kuli baku, diberi hak garap atas satu atau lebih unit kulian tergantung dari kontribusi yang mampu diberikan kepada desa. Memudarnya sistem tanah komunal di Ngandagan menyebabkan tanah pekulen ini kemudian dimiliki secara perseorangan dan turun temurun oleh kuli baku. ${ }^{5}$ Atas inisiatif kepala desa, desa mengambil 90 (sembilan puluh) ubin untuk diberikan kepada masyarakat yang tidak memiliki tanah untuk dikelola secara bergantian dengan menjadi buruh kuli pada tanah kuliannya. ${ }^{6}$ Seluruh luasan tanah pekulen ini telah dilengkapi dengan letter $\mathrm{C}$ dan dibebani dengan Pajak Bumi Dan Bangunan (PBB) yang harus ditanggung oleh kuli baku meskipun sebagian darinya digarap oleh buruh kulian. Sistem ini masih bertahan hingga sekarang, bahkan mengalami dinamika seiring

Boedi Harsono, 2003, Hukum Agraria Indonesia, Sejarah Pembentukan Undang-undang Pokok Agraria, Isi, dan Pelaksanaannya, Djambatan, Jakarta, hlm. 62.

Hal ini menghasilkan tanah kulian, yaitu bidang-bidang tanah yang merupakan persilisasi dari tanah komunal desa.

Ibid. hlm. 43.

Moh. Shohibuddin dan Ahmad Nashih Luthfi, Op.cit., hlm. 42. Secara umum, tanah di desa-desa Jawa pada masa lampau di bagi menjadi 3 yaitu tanah yasan yaitu tanah milik pribadi yang hak kepemilikan atasnya berasal dari kenyataan bahwa pemiliknya (atau nenek moyangnya) adalah orang yang pertama kali membuka tanah dari hutan. Kedua, adalah tanah pekulen, dan ketiga adalah tanah bengkok yaitu tanah sawah milik desa yang diperuntukkan bagi para pamong desa sebagai "gaji” selama mereka menduduki jabatan pamong itu. Tanah pekulen dalam perkembangannya menunjukkan kontrol desa kian melemah dan hak warga desa yang menguasai bidang tanah semakin kuat serupa dengan hak milik penuh (yasan). Istilah pekulen merupakan penyebutan lain untuk gogolan, sedangkan sikep merupakan nama lain untuk kuli baku. Hal ini menghasilkan tanah kulian, yaitu bidang-bidang tanah yang merupakan persilisasi dari tanah komunal desa.

Tanah ini disebut dengan buruhan. Yaitu petak sawah yang berasal dari sawah kulian yang disisihkan oleh pemegangnya untuk diberikan sebagai hak garap kepada petani tak bertanah. Hal ini menimbulkan hubungan patron-klien antara penggarap dan kuli baku. 
perkembangan zaman.

Keberadaan tanah pekulen ini menarik dikaji pada masa kini. Hal ini karena secara de jure UUPA telah memberikan rambu-rambu, namun secara de facto masih sulit untuk diimplementasikan dengan melihat karakter tanah ini. Meskipun secara formal jenis tanah ini belum sepenuhnya dapat diintegrasikan dalam pola penguasaan hak atas tanah hukum nasional, namun pada kenyataannya tanah ini menjadi penyumbang kesejahteraan bagi masyarakat desa dan di sisi lain menyumbang konflik agraria karena kepastian hukum yang sulit dirumuskan.Contohnya ketika legalisasi tanah pekulen sulit dilakukan, maka terjadi saling klaim pemilikan tanah yang berujung status quo. Kondisi ini menghambat kegiatan pembangunan karena tidak jelasnya status hak atas tanah. Hal ini semakin rumit dengan lahirnya Keputusan Menteri Agraria dan Tata Ruang/Badan Pertanahan Nasional No. 9 Tahun 2015 tentang Tata Cara Penetapan Hak Komunal Atas Tanah Masyarakat Hukum Adat dan Masyarakat yang berada dalam Kawasan Tertentu yang seakan menyamakan tanah ulayat dan tanah komunal.Secara karakteristik penamaan tanah ulayat dan tanah komunal untuk Jawa dan luar Jawa memiliki perbedaan. Sistem pengaturan tanah ulayat selama ini mensyaratkan adanya entitas masyarakat hukum adat dengan pengakuannya oleh negara, sedangkan di Jawa hal ini tidak selalu ada. Bagaimanakah pengaturan tanah pekulen dalam struktur hukum agraria nasional? Hal ini akan sangat bergantung dari karakteristik tanah serta norma hukum yang dijadikan standar negara. Keadaan kekosongan hukum yang ada memerlukan kajian mengingat bahwa untuk membentuk hukum tergantung arah kebijakan politik negara, sistem nilai masyarakat, serta berbagai aspek lain yang melingkupinya termasuk peluang regulasi yang ada. Berdasarkan uraian di atas, tulisan ini bermaksud menampilkan keberadaan tanah pekulen dalam struktur hukum agraria di Jawa

\section{B. Pembahasan \\ 1. Pengertian Tanah Pekulen dan Persebaran- nya}

Diskursus mengenai konsep hak atas tanah menurut hukum adat secara tidak langsung berkaitan dengan lingkungan geografis dan adat daerah yang sangat heterogen di Indonesia. Hal ini mengakibatkan penyebutan berbeda satu dengan daerah lain meskipun memiliki esensi yang sama, termasuk tanah pekulen atau yang sering disebut sanggan, kulen atau gogol. Menurut Moedjiono dalam BF. Sihombing, tanah pekulen adalah gaji pegawai berupa tanah yang diberikan oleh pemerintah kepada masyarakat yang bukan pejabat desa. ${ }^{7}$ Hal ini terjadi pada zaman kolonial sebagai penghargaan dari pemerintah kepada warga masyarakat yang berjasa. Pengertian ini mengarah pada konsep tanah pekulen sebagai modal untuk memenuhi kewajiban tanam paksa maupun pembayaran pajak dalam konsep cultuurstelsel yang melahirkan komunalisme tanah yang berpusat di desa-desa Jawa oleh Belanda. Faktanya bahwa justru Belanda memanfaatkan keberadaan pertanian di desa untuk diakui sepihak sebagai milik pemerintah berdasar asas domein verklaring. Definisi gaji pegawai lekat dengan pengertian tanah bengkok yang ada dalam struktur agraria pedesaan Jawa.

M. Billah dalam Sediono menyebutkan bahwa tanah pekulen adalah tanah milik individu yang tidak dapat dijual kepada orang dari desa lain karena ada hak-hak tertentu dari desa atas tanah tersebut. ${ }^{8}$ Hak tersebut antara lain berupa larangan menjualnya kepada warga di luar desa. Pendapat lain menyebutkan bahwa tanah pekulen adalah sawah komunal milik desa yang diberikan kepada penduduk inti desa. ${ }^{9}$ Berbagai pendapat tersebut memiliki konsep dasar yang sama yaitu adanya

\footnotetext{
Mudjiono dalam BF Sihombing, 2005, Evolusi Kebijakan Pertanahan Dalam Hukum Tanah Indonesia, Toko Gunung Agung, Jakarta, hlm. 106.

Ranneft dalam M. Billah, et al., 2008, Sistem Pemilikan Tanah dan Masyarakat Desa di Jawa Pada Abad XIX dalam "Dua Abad Penguasaan Tanah: Pola Penguasaan Tanah Pertanian Di Jawa Dari Masa Ke Masa”, Yayasan Obor Indonesia, Jakarta, hlm. 307.

Moh. Shohibuddin dan Ahmad Nashih Luthfi, Loc.cit.
} 
sifat komunal dari desa baik yang bersifat langsung (pengaturan peruntukan dan pengawasan langsung oleh desa) maupun tidak langsung (desa hanya mengawasi penggunaannya oleh individu warga).

Istilah kuli di wilayah Bagelen (Purworejo) berasal dari bahasa sansekerta yang berarti petani, bukan kuli (koeli) dalam arti buruh yang diserap dari terminologi sejarah perkebunan perusahaan Belanda di Indonesia (Sumatera timur). Di luar wilayah Bagelen, istilah kuli sebagai penggarap tanah juga dikenal. Kuli sama dengan gogol atau sikep yakni pihak yang diberi kuasa atas tanah komunal. ${ }^{10}$ Gogol/sikep/kuli di desa adalah golongan anggota masyarakat yang melaksanakan tugas gawe desa (tugas-tugas sosial dalam pemerintahan desa). Tugas tersebut berupa rapat-rapat desa, jaga malam, gotong royong, penanggulangan kebakaran, banjir, serta bencana alam lain dan bentuk partisipasi lainnya. ${ }^{11}$ Para gogol/sikep/kuli inilah yang memiliki kewajiban-kewajiban utama terhadap desa, meskipun dalam kenyataannya hal tersebut dapat diserahkan pada para penggarap/ buruhnya. Hal ini sejalan dengan pembagian warga masyarakat desa oleh vanVollenhoven yang menempatkan kuligogol, sikep, atau kuli kenceng sebagai golongan terkuat. ${ }^{12}$

Stratifikasi penduduk secara langsung berpengaruh terhadap status penguasaan tanah tradisional. ${ }^{13}$ Pertama, tanah yasan, yasa/yoso, tanah dimana hak seseorang berasal dari kenyataan bahwa ia/ leluhurnya yang pertama membuka/mengerjakan tanah. Tanah ini oleh UUPA dikonversi menjadi hak milik. Kedua, tanah norowito, gogolan, pekulen, playangan, kesikepan, adalah tanah pertanian milik bersama yang darinya para warga dapat memperoleh bagian untuk digarap baik secara bergilir atau tetap dengan syarat tertentu. Persyaratan tersebut meliputi sudah kawin, punya rumah dan pekarangan, dan kerja wajib desa. Konsep hukum barat meletakkan dalam kategori tanah komunal. UUPA mengkonversi hak atas tanah ini menjadi hak milik bagi penggarapnya yang terakhir. Ketiga, tanah titisara, bondo desa, kas desa yaitu tanah milik desa yang biasanya disewakan, disakapkan dengan cara dilelang sedangkan hasilnya untuk anggaran rutin atau pemeliharaan desa. Keempat, tanah bengkok, tanah milik desa yang diperuntukkan bagi pejabat desa terutama lurah dan hasilnya dianggap gaji selama menduduki jabatan.

Tanah pekulen adalah jenis tanah adat yang memiliki karakter komunalistik yang melekat pada kewenangan desa. Jenis tanah ini memiliki penamaan yang tidak sama tergantung masingmasing wilayah. Ciri utama sekaligus pembedanya adalah sifat tanah yang dikelola oleh desa dan hak garapnya ada pada warga desa baik secara tetap maupun digilir. Berikut ini beberapa istilah untuk sawah komunal desa.

Tabel 1. Istilah Sawah Komunal Di Berbagai Daerah

\begin{tabular}{|c|c|c|c|}
\hline Daerah & Istilah sawah komunal & $\begin{array}{l}\text { Istilah penggarap/ yang } \\
\text { melakukan kerja wajib }\end{array}$ & $\begin{array}{c}\text { Istilah tanah garapan yang } \\
\text { digilirkan }\end{array}$ \\
\hline Cirebon & Sawah desa & $\begin{array}{l}\text { Sikep, kuren tani, tani laku } \\
\text { gawe, cekel gawe, jalma pegang } \\
\text { sawah, tani buku, cacah }\end{array}$ & Bagian carik, lakonangawe \\
\hline Tegal & $\begin{array}{l}\text { Playangan. Bumen-bumen, } \\
\text { sawah desa }\end{array}$ & Kuli, janggol, kerik sikep & $\begin{array}{l}\text { Bakonkuli, janggolan, bagian, } \\
\text { bagian janggol, bagian carik }\end{array}$ \\
\hline Banyumas & $\begin{array}{l}\text { Playangan, prutahan, sawah } \\
\text { kuwu, lanyah }\end{array}$ & Kuli, kerik & Bagi, bagian, caton \\
\hline Pekalongan & $\begin{array}{l}\text { Playangan, sawah desa, sawah } \\
\text { sanggan }\end{array}$ & Sikep & Bagian, sikep \\
\hline
\end{tabular}

Devy Dhian Cahyati, 2014, Konflik Agraria Di Urutsewu, Pendekatan Ekologi Politik, STPN Press, Yogyakarta, hlm. 191.

Suhartono, 1991, Apanage dan Bekel, Tiara Wacana, Yogyakarta, hlm. 25.

M. Billah, et al., Loc. Cit.

Gunawan Wiradi, 2008, Pola Penguasaan Tanah Dan Reforma Agraria dalam "Dua Abad Penguasaan Tanah: Pola Penguasaan Tanah Pertanian Di Jawa Dari Masa Ke Masa,” Yayasan Obor Indonesia, Jakarta, hlm. 355. 


\begin{tabular}{|c|c|c|c|}
\hline Bagelen & $\begin{array}{l}\text { Sanggan, lanyah, baku, sawah } \\
\text { desa }\end{array}$ & Kuli, kerik & Bagian, sanggan, kulen \\
\hline Semarang & & Wong tani, sikep & Bangku, sanggeman \\
\hline Jepara & $\begin{array}{l}\text { Sawah desa, bumi, kebumen, } \\
\text { norowito, sewan }\end{array}$ & $\begin{array}{l}\text { Wong tani, wong kenceng, sikep, } \\
\text { gogol }\end{array}$ & Bagian, sanggeman, bangku \\
\hline Rembang & $\begin{array}{l}\text { Krajan, jung, bakon, } \\
\text { kramanan, ideran, baratan, } \\
\text { auman, bagen }\end{array}$ & $\begin{array}{l}\text { Kraman kenceng, gogol, sikep, } \\
\text { kuli kenceng }\end{array}$ & $\begin{array}{l}\text { Bangku, selakon, bakonkuli, } \\
\text { kramanan, kulen, bagen }\end{array}$ \\
\hline Madiun & Rojo & Kuli kenceng & $\begin{array}{l}\text { Kulen, bangku, bagian, } \\
\text { selupit, sekencengajangan, } \\
\text { sepangkonsanggan }\end{array}$ \\
\hline Kediri & Kongsen, lanyah & Kuli kenceng & Kulen, catu, anjangan, bangku \\
\hline Surabaya & Sawah desa, lanyah, kongsen & Gogol, kraman & Caton, kramanan, catu \\
\hline Pasuruan & $\begin{array}{l}\text { Lanyah, kongsen, kramanan, } \\
\text { sawah duweke wong akeh, } \\
\text { sawah desa, negoro, rojo }\end{array}$ & Gogol, gogol sawah, wong tani & Bagian \\
\hline Probolinggo & & Wong kenceng, orang kenceng & \\
\hline Madura & & Oring kuat, tani & \\
\hline
\end{tabular}

Sumber : Hiroyashi Kano, ${ }^{14} 2008$.

Secara khusus, persebaran desa yang mempunyai tanah norowito/gogolan/kesikepan/pekulen belum dapat diketahui secara pasti. Beberapa literaturmenyebut berada di daerah areal tebu, padi, dan nila yang terdapat di Jawa Tengah, Jawa Timur, dan di Jawa Barat. Desa-desa di Jawa Barat sebagai penghasil kopi relatif bersifat individual dengan kontur dataran tinggi daripada sifat komunal yang dimiliki desa di Jawa Tengah dan Jawa Timur. ${ }^{15}$ Beberapa daerah lainnya seperti Bagelen di Karesidenan Kedu (Purworejo, Kebumen, Temanggung, Wonosobo, dan Magelang), Tegal, Probolinggo dan beberapa daerah lain termasuk di Sidoarjo juga mengenal tanah gogolan/pekulen yang menarik dilakukan penelitian.

Tanah bagi masyarakat desa menjadi faktor produksi/ modal. Pemilikan dan penguasaan tanah menjadi simbol status dan sumber kesejahteraan. Meskipun demikian faktanya tanah pekulen individual tetap terjaga kebersamaannya melalui pengakuan adanya kewenangan yang dimiliki oleh desa. Hal ini sejalan dengan pendapat A. Sonny Keraf dan kaum Stoasebagaimana diacu oleh Kurnia Warman bahwa ciri atau ukuran utama adanya kepemilikan bersama (co-ownership) adalah adanya kesatuan yang tidak terpisahkan dari benda atau hak yang menjadi milik bersama itu. Kepemilikan bersama erat hubungannya dengan pencapaian keadilan karena sasarannya adalah keharmonisan, keserasian, dan keutuhan kosmopolis. ${ }^{16}$

\section{Sejarah Penguasaan Tanah Pekulen dan Dinamika Masyarakat}

Tanah di Indonesia mengalami penataan dan pengaturannya pasca lahirnya UUPA tahun 1960. UU ini mengakhiri dualisme hukum agraria yang bersumber atas hukum barat dan hukum adat. Penerapan hukum agraria nasional menetapkan adanya konversi terhadap hak atas tanah yang bersumber dari hukum barat dan hukum adat menjadi hak atas tanah menurut hukum nasional.

Penguasaan tanah sudah terjadi dengan berdasar alur sejarah yang bersesuaian dengan daerah masing-masing di Indonesia. Secara garis besar, konsep penguasaan tanah masa lalu merupakan dasar dan cikal bakal status hak atas tanah pada masa kini. Konsep ini tidak hanya bersumber dari hukum adat yang memang berkonsepsi komunalistik religius, namun ternyata juga berasal dari hukum barat yang

14 Hiroyoshi Kano, 2008, Sistem Pemilikan Tanah Dan Masyarakat Desa Di Jawa Pada Abad XIX Dalam "Dua Abad Penguasaan Tanah: Pola Penguasaan Tanah Pertanian Di Jawa Dari Masa Ke Masa," Yayasan Obor Indonesia, Jakarta, hlm. 58-59.

5 Gunawan Wiradi, Op. cit., hlm. 358.

16 Kurnia Warman, 2006, Ganggam Bauntuak Menjadi Hak Milik, Penyimpangan Konversi Hak Tanah di Sumatera Barat, Andalas University Press, Padang, hlm. 28-31. 
berkonsepsi individualistik liberal. ${ }^{17}$

Literatur menunjukkan bahwa terdapat perbedaan pendapat mengenai sejarah lahirnya tanah komunal di Indonesia. Pendapat pertama menyebutkan bahwa sistem tanah komunal timbul sebagai akibat adanya perubahan sistem yang dilaksanakan oleh para raja dan pemerintah kolonial.Sistem komunal atas tanah bukan asli dari masyarakat Indonesia namun bersifat artifisial atau buatan. Hal ini didasari pada fakta bahwa sebelum pemerintah Belanda ada di Indonesia, desa-desa tidak membentuk suatu masyarakat dengan batas geografis yang jelas, sehingga penentuan garis batas dan pembentukan wilayah (afronding) merupakan hasil pemerintah kolonial. ${ }^{18}$ Keberadaan desa-desa inilah yang menjadi tumpuan cultuurstelsel (tanam paksa) pada abad XIX yaitu periode 1830-1870 yang diterapkan pemerintah kolonial Belanda. Hal ini bertujuanuntuk membuat Jawa menjadi tanah jajahan yang menguntungkan melalui penarikan dan sistem pajak tanah. Kebijakan yang diambil dalam rangka pengorganisasian tanah yaitu dengan menyerahkan pengelolaan semua tanah baik pendistribusian, penggunaan, dan penyerahan hasil bumi dalam koordinasi desa. Akibat kebijakan ini pemilikan tanah justru menjadi beban karena adanya wajib kerja bagi para penggarap tanah yang sangat besar. Penggarapan tanah justru menjadi beban yang mendorong untuk pendistribusian tanah untuk ditanggung bersama dengan warga desa lain. Pembagian kembali tanah-tanah garapan antara para warga desa secara komunal yang teratur dan berkala dilakukan sebagai tindak lanjutnya. Proses ini didorong pemerintah kolonial karena pengawasan terhadap komoditas tanaman dan penggunaan sarana pengairan dianggap lebih efisien dan mudah jika dilakukan dengan gabungan petak sawah daripada persil terpisah.
Pendapat kedua menyebutkan, baik sistem pribadi maupun komunal merupakan bentuk asli yang ada sejak dulu. ${ }^{19}$ Hal ini didasari konsepsi komunalistrik religius yang menjadi karakter asli masyarakat Indonesia, sehingga masyarakat memang telah terbagi dalam mengelola tanahnya baik tanah pribadi yang dimiliki sendiri maupun tanah bersama yang berada dalam pengawasan desa.

Daerah-daerah di wilayah kerajaan (vorstenlanden) seperti Yogyakarta dan Surakarta menggunakan sistem apanage (lungguh) dimana raja merupakan pemilik semua tanah di wilayah kerajaan dan memberi gaji para abdi dalem dan priyayi dengan tanah lungguh atau tanah bengkok. Kekuasaan sultan absolut atas tanah di wilayah kerajaannya, sedangkan rakyat (kawula dalem) hanya diperkenankan menempati sebagian tanah. Rakyat memiliki hak anggadhuh dengan status turun temurun. Status sultan ini sebagaimana bunyi Pasal 1 Rijksbladvan Sultanaat Djogjakarta No. 16 Tahun 1918:

Sakabehing bumi kang ora ana yektine kadarbe ing liyan mawa wewenange gendom dadi bumi kagungane keraton ingsun Ngajogjakarta. ${ }^{20}$

Setelah reorganisasi tanah di keraton Yogyakarta Tahun 1917 yang dimulai dengan penghapusan sistem apanage, tanah diserahkan pengelolaannya kepada kalurahan. Tanah menjadi milik komunal warga kampung dengan status hak pakai (gebruiksrechten). Selain lahirnya Hak pakai secara turun temurun (erfelijkgebruiksrechten), pada tahun 1925 Sultan memberikan tanah kepada warga masyarakat dengan hak milik pribadi. Ada sebagian penduduk yang memperoleh hak pakai dari kelurahan dan ada sebagian golongan yang diberikan hak milik (andarbeni). ${ }^{21}$ Tanah di Indonesia bukan hanya merupakan suatu lingkungan jurisprudensi

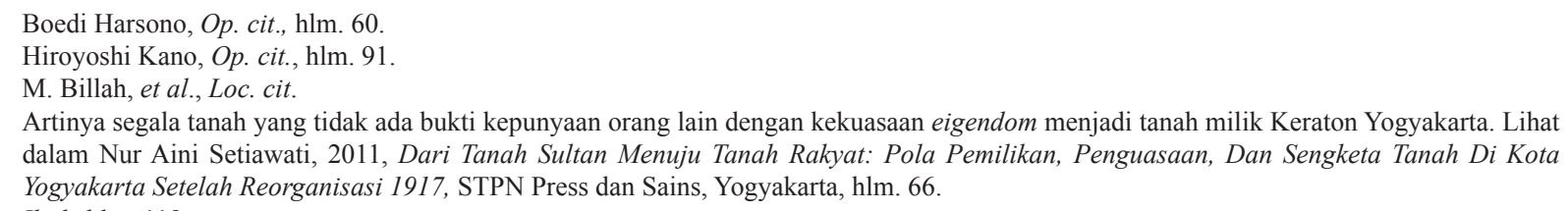


pada taraf lokal melainkan adat kebiasaan yang mengatur seluruh hubungan antara penggarap tanah dengan negara yaitu raja. ${ }^{22}$

Pendapat berbeda dikemukakan oleh van Vollenhoven yang secara lugas menyebutkan bahwa ada banyak jenis hak adat menurut hukum adat Jawa yang berlaku bahkan jauh sebelum Belanda datang, yang kemudian oleh pemerintah dibagi menjadi 3 jenis penguasaan tanah yaitu erfelijktindividueelbezit atau hak milik pribumi yang dapat diwariskan, communalbezit atau hak milik komunal, dan gebruiksaandelen in communaalbezit atau hak milik komunal dengan pemakaian secara bergiliran. ${ }^{23}$ Selain itu disebutkan juga bahwa seluruh daerah Jawa khususnya Jawa Tengah dan Jawa Timur termasuk daerah Vorstenlanden $\left(\mathrm{Kedu}^{24}\right.$, Surakarta, dan Yogyakarta) memiliki jenis tanah komunal yang merupakan bagian tanah ulayat desa. Hal ini sekaligus menolak doktrin domein raja bahwa semua tanah adalah milik raja. Tanah ulayat desa ada terlebih dahulu sebelum dipenetrasi dengan absolutisme raja.Secara sederhana berikut ditampilkan perbedaan antara tanah komunal dan tanah perorangan/ individual.

Tabel 2. Perbedaan Karakteristik Tanah Komunal dan Tanah Perorangan

\begin{tabular}{|c|c|c|c|}
\hline No & Karakter & Tanah Individual & Tanah Komunal \\
\hline 1. & Pemilikan & Pemilik tanah adalah perseorangan & $\begin{array}{l}\text { Pemilik tanah adalah seluruh } \\
\text { masyarakat desa }\end{array}$ \\
\hline 2. & Penguasaan & Penguasaan secara pribadi & Penguasaan secara bersama-sama \\
\hline 3. & $\begin{array}{l}\text { Peruntukan/ } \\
\text { penggunaan }\end{array}$ & $\begin{array}{l}\text { Biasanya untuk rumah, pekarangan, sawah, } \\
\text { serta kebun. }\end{array}$ & $\begin{array}{l}\text { Digunakan untuk sawah desa, } \\
\text { tanah penggembalaan, kebun, dan } \\
\text { perumahan warga. }\end{array}$ \\
\hline 4. & Pengawasan desa & $\begin{array}{l}\text { Memastikan dilakukan penguasaan secara } \\
\text { nyata dan efektif oleh pemilik. Dapat ditarik } \\
\text { jika tidak dimanfaatkan. }\end{array}$ & $\begin{array}{l}\text { Desa berwenang mengatur dan } \\
\text { menentukan penguasaan, peruntukan, } \\
\text { dan penggunaannya. }\end{array}$ \\
\hline 5. & Peralihan & $\begin{array}{l}\text { Dapat dialihkanoleh pemilik, namun tidak } \\
\text { boleh kepada orang di luar desa. Jika pemilik } \\
\text { meninggal dunia/ meninggalkan desa, desa } \\
\text { akan mengambil dan menyerahkan kepada } \\
\text { orang lain }\end{array}$ & $\begin{array}{l}\text { Warga desa hanya berhak } \\
\text { menggarap, tidak boleh dialihkan } \\
\text { kepada orang lain }\end{array}$ \\
\hline 6. & $\begin{array}{l}\text { Kewajiban ke } \\
\text { desa }\end{array}$ & Tidak ada & $\begin{array}{l}\text { Wajib melakukan kerja ke desa } \\
\text { (kerigan) baik kerja bakti, ronda } \\
\text { malam, dll. }\end{array}$ \\
\hline
\end{tabular}

Sumber: Olahan Penulis, 2016.

3. Sejarah Penguasaan Tanah Pekulen dan Dinamika Masyarakat

Perubahan dan perkembangan zaman merupakan hal yang alami. Transformasi masyarakat dari bersifat sederhana menuju masyarakat yang kompleks senantiasa terjadi dalam kaitannya dengan perubahan politik, ekonomi, sosial, bahkan hukum, seperti konsep hak atas tanah berdasarkan pada hukum adat. Konsep ini bersifat tidak tertulis, sehingga eksistensinya rentan dan mengalami perubahan. Hal ini dipengaruhi oleh ikatan yang ada dari masyarakat desa sebagai lingkungan hidupnya.

Struktur agraria merupakan sebaran atau distribusi penguasaan formal dan penguasaan operasional serta alokasi pembentukan sumbersumber agraria yang memiliki relasi satu sama lain. Komponen utama dalam struktur agraria yaitu pemilikan, penguasaan, dan peruntukan atau penggunaan sumber agraria oleh subjek agraria yaitu pemerintah sebagai pemegang kekuasaan

\footnotetext{
22 Svein Aass, 2008, Relevansi Teori Makro Chayanov dalam Dua Abad Penguasaan Tanah: Pola Penguasaan Tanah Pertanian Di Jawa Dari Masa Ke Masa, Yayasan Obor Indonesia, Jakarta, hlm. 146.

23 Cornelis vanVollenhoven, 2013, Orang Indonesia dan Tanahnya, STPN Press, Yogyakarta, Hlm: 21.

24 Lihat Cornelis vanVollenhoven, Ibid., hlm. 17. Dalam catatan sejarah wilayah Kedu termasuk dalam Vorstenlanden yang kemudian oleh Sultan diberikan kepada pemerintah Belanda sebagai imbalan jasa karena membantu menumpas pemberontakan.
} 
formal, petani, dan pengusaha atau korporasi. ${ }^{25}$ Pemilikan mengarah pada hubungan subjek dan objek yang diformalkan dalam sebuah hubungan hukum yang kuat.

Fitzgerald dalam Kurnia mengemukakan ciri pemilikan, pertama, pemilik memiliki hak untuk memiliki barangnya. Kedua, pemilik biasanya mempunyai hak untuk menggunakan dan menikmati barang yang dimilikinya yang pada dasarnya merupakan kemerdekaan bagi pemilik untuk berbuat terhadap barangnya. Ketiga, pemilik mempunyai hak untuk menghabiskan, merusak, mengalihkan barangnya kepada orang lain.

Keempat, Pemilikan mempunyai ciri tidak mengenal jangka waktu, berlaku selamanya. Kelima, pemilikan mempunyai ciri yang bersifat sisa dan tak terbatas. Tanah mungkin digadaikan, dibagikan dan lain-lain, namun pemilik masih memiliki tanah yang ada. Hak tadi menumpang di atas hak milik yang asli/ ius in realiena. ${ }^{26}$

Hak milik sangat kuat, namun tetap harus berfungsi sosial, yaitu agar barang tidak dimonopoli oleh pemiliknya, namun harus memberi faedah bagi kehidupan masyarakat (fungsi sosial) sebagaimana falsafah Pancasila yang menggambarkan manusia sebagai makhluk dwi tunggal baik sebagai manusia pribadi maupun makhluk sosial.

Secara etimologi, penguasaan berasal dari kata "kuasa" yang berarti kemampuan atau kesanggupan berbuat sesuatu, kekuatan atau kewenangan atas sesuatu atau untuk menentukan (memerintah, mewakili, mengurus, dan sebagainya) sesuatu itu. Jadi menurut bahasa, penguasaan atas tanah dapat diartikan sebagai proses, cara atau perbuatan untuk menguasai sebidang tanah yang berisikan wewenang dan kesanggupan dalam menggunakan dan memanfaatkannya untuk kelangsungan hidup. ${ }^{27}$ Penguasaan harus secara faktual dalam kenyataan.
Penggunaan dan pemanfaatan menunjuk pada cara sebidang tanah diusahakan secara langsung, baik untuk usaha pertanian, dan nonpertanian serta pemanfaatan yang beraneka ragam seperti rumah toko (ruko), perumahan, sawah, ladang, dan sebagainya.

Hukum merupakan konkritisasi nilai-nilai yang terbentuk dari kebudayaan suatu masyarakat. ${ }^{28}$ Masyarakat sebagai subyek pembentuk hukum mengembangkan perangkat aturan dalam rangka menciptakan ketertiban dan keteraturan hidup dengan berdasarkan pada sistem nilai dan adat yang ada, hidup, tumbuh dan berkembang di masyarakat. Hukum yang ada tergantung pada sistem nilai dan budaya masyarakat yang bersangkutan. Pada tataran kenegaraan, hukum harus bersifat nasional sehingga ada berbagai kepentingan dan nilai yang belum terwadahi. Hukum merupakan sistem yang terdiri dari perangkat aturan yang menurut Lawrence $\mathrm{M}$. Friedman yang diacu Esmi Warassih terbagi dalam 3 (tiga) komponen sistem hukum berupa struktur, substansi, dan kultur. ${ }^{29}$ Struktur hukum agraria dapat dipahami sebagai kelembagaan yang diciptakan dalam sistem hukum agrarianya dengan berbagai macam fungsi untuk mendukung bekerjanya sistem hukum. Pada tataran negara Indonesia, Kementerian Agraria dan Tata Ruang/Badan Pertanahan Nasional dalam rangka mengemban tugas mewujudkan tanah untuk sebesar-besar kemakmuran rakyat.

Persoalan tanah sawah berdasar hukum adat, sangat lekat dengan insitusi desa sebagai unit pemerintahan terkecil dalam sistem desentralisasi sebagaimana diatur dalam Undang-undang Nomor 6 Tahun 2014 tentang Desa. ${ }^{30}$ Desa mengalami dinamika seiring perkembangan zaman. Pada masa lalu desa dibentuk dalam rangka memenuhi kebutuhan tenaga kerja maupun dalam rangka pengelolaan tanah untuk keperluan Belanda dan

\footnotetext{
Gunawan Wiradi, Op. cit., hlm. 351.

Kurnia Warman, Op. cit., hlm. 25.

Kurnia Warman, Op. cit., hlm. 23.

Esmi Warassih, 2005, Pranata Hukum Sebuah Telaah Sosiologis, Suryandaru Utama, Semarang, hlm. 103.

Ibid., hlm. 104.

Menurut Pasal 1 angka 1 UU No. 6 Tahun 2014 definisi Desa adalah kesatuan masyarakat hukum yang memiliki batas wilayah yang berwenang untuk mengatur dan mengurus urusan pemerintahan, kepentingan masyarakar setempat berdasarkan berdasarkan prakarsa masyarakat, hak asal usul, dan/hak tradisional yang diakui dan dihormati dalam sistem pemerintahan Negara Kesatuan Republik Indonesia.
} 
kerajaan, sekarang desa diharapkan jauh lebih demokratis dan otonom. Sebagai institusi dengan pola sosial dan kehidupan kemasyarakatan yang lebih intensif, maka masyarakat desa dengan basis kehidupan agraris/ pertanian di dunia terbagi dalam beberapa bentuk yang dapat dilihat pada tabel 2 di bawah ini.

Tabel 3. Bentuk Dasar Masyarakat

\begin{tabular}{|c|c|c|c|}
\hline Kriteria & Bentuk Asia & Bentuk Klasik-Antik & Bentuk Jerman \\
\hline Gemeinschaft dasar & $\begin{array}{l}\text { "suku" (tribe) atau } \\
\text { subbagian-nya }\end{array}$ & $\begin{array}{l}\text { "kota" (city) ("masyarakat } \\
\text { prajurit") }\end{array}$ & $\begin{array}{l}\text { "kampung" (village) } \\
\text { (kelompok pemilik tanah } \\
\text { yang bertetangga) }\end{array}$ \\
\hline $\begin{array}{l}\text { Hausgemeinschaft } \\
\text { keluarga }\end{array}$ & $\begin{array}{l}\text { Keluarga besar } \\
\text { patriarkal }\end{array}$ & $\begin{array}{l}\text { Keluarga kecil patriarkal } \\
\text { (dengan otoritas kuat di } \\
\text { tanagn kepala keluarga) }\end{array}$ & $\begin{array}{l}\text { Keluarga kecil patriarkal } \\
\text { (dengan otoritas yang } \\
\text { melemah ditangan keluarga) }\end{array}$ \\
\hline Prinsip "persamaan" & $\begin{array}{l}\text { Substantif } \\
\text { (distribusi mendasar } \\
\text { kemampuan dan } \\
\text { kebutuhan) }\end{array}$ & Substantif & Formal \\
\hline $\begin{array}{l}\text { Kelaziman pemilikan } \\
\text { tanah pribadi }\end{array}$ & $\begin{array}{l}\text { Heredium (bidang } \\
\text { tanah untuk } \\
\text { perumahan dan } \\
\text { kebun) }\end{array}$ & $\begin{array}{l}\text { Fundus (bidang tanah untuk } \\
\text { perumahan, kebun, dan } \\
\text { sebagian tanah milik umum } \\
\text { dan diduduki melalui hak } \\
\text { senioritas) }\end{array}$ & $\begin{array}{l}\text { Hufe (bidang tanah untuk } \\
\text { perumahan, kebun, dan bidang } \\
\text { kecil tanah pertanian serta } \\
\text { bagian dari milik desa) }\end{array}$ \\
\hline
\end{tabular}

Keterangan: Tulisan pada kolom yang ditulis tebal adalah ciri masyarakat pedesaan di Indonesia.

Sumber : Hiroyashi Kano, ${ }^{31} 2008$.

Masyarakat pedesaan di Indonesia identik dengan gambaran bentuk masyarakat pedesaan klasik-antik meskipun bukanlah masyarakat kota. Umumnya terdiri atas keluarga kecil patriarkal dengan kekuasaan yang besar pada kepala keluarga. Kehidupan sosialnya didasari oleh prinsip persamaan yang substantif artinya distribusi didasari kemampuan dan kebutuhan. Pemilikan tanah secara pribadi umumnya digunakan untuk perumahan, kebun, dan sebagian tanah milik umum serta diduduki melalui hak senioritas yang diberikan desa.

Fenomena penguasaan (baik formal maupun operasional) dari tanah komunal pada tingkal lokal terjadi di Desa Ngandagan, Kecamatan Pituruh Kabupaten Purworejo. Tanah pekulen yang telah mengalami penguatan dengan hak individu yang dipengaruhi oleh hak ulayat desa. Desa masih memiliki kewenangan untuk mengatur dan menentukan pemilikan, penguasaan, dan penggunaannya. Atas dasar inilah kemudian lahir istilah tanah pekulen atau kulian (tanah milik individu masyarakat yang diperoleh dari desa), dan tanah buruhan (bagian tanah pekulen yang diambil oleh desa untuk dibagikan kepada petani yang tidak memiliki tanah). Kebijakan ini mengalami perubahan sesuai tuntutan dan kebutuhan masyarakat, yaitu luas tanah pekulen yang dipotong tidak hanya seluas 300 ubin namun kadang lebih sempit karena mengikuti plot tanah sawah yang ada serta tanah buruhan seluas 90 ubin dibagikan untuk 2 rumah tangga petani. ${ }^{32}$

Dinamika dan perkembangan pengelolaan tanah pekulen yang terdiri atas tanah kulian dan buruhan sangat dipengaruhi oleh kontestasi berbagi aktor yang berperan. Baik para kulian, buruh kuli, aparat desa, maupun stakeholder lain masing-masing memiliki interpretasi yang berbeda. Hiroyoshi Kano menyebutkan ada 3 cara redistribusi tanah oleh desadiantaranya melalui kebijakan yang diinisiasi 
oleh kepala desa/ institusi formal. ${ }^{33}$ Hampir semua pembaharuan agrariadilakukan atas dasar inisiatif pemerintah, sehingga begitu minat pemerintah berubah (demi kepentingannya) maka habislah hasil-hasil positif yang mungkin pernah dicapai oleh pembaruan agraria. Inisiatif dan kedermawanan pemerintah ini oleh Powelson dan Stockyang disitir oleh Noer Fauzi disebut dengan istilah reformbygrace. Pembaruan ini tidak sustainable karena tergantung pada pasar politik menurut istilah Yushiro Hayami. ${ }^{34}$ Sifat unsustainable ini seringkali membuat sebuah kebijakan khususnya agraria seringkali mengalami pembalikan atau perlawanan bahkan membawa kegagalan.

Perubahan masyarakat menunjukkan kecenderungan yang mengarah pada penguatan hak individu dan tuntutan atas kepastian hukum yang berhadapan dengan kuatnya solidaritas masyarakat dalam mempertahankan hak ulayat desanya. Pola individualisasi ini dapat dibatasi dengan menjaga pola pergiliran pemanfaatan tanah yang memberikan manfaat penguasaan secara individual. Ketidaksepahaman tentang kedudukan dan pengelolaan tanah pekulen ini disebabkan masih belum dicapainya suatu kepastian hukum dalam pengaturannya. Permasalahan yang harus diperhatikan adalah, karakter tanah pekulen khususnya tanah buruhan yang bersifat kolektif yang bertujuan untuk memberikan kemanfaatan dan keadilan bagi masyarakat khususnya yang tidak bertanah. Distribusi tanah pekulen yang dilakukan oleh desa secara revolusioner, selain bertujuan untuk pemerataan juga untuk menjaga prinsipprinsip penguasaan tanah,diantaranya tentang pembatasan pemilikan tanah. Kecenderungan yang terlihat pada akhir tahun 1990-an menunjukkan perubahan dalam struktur agraria, diantaranya pertama dalam hal pemilikan khususnya tanah kulian beberapa sudah beralih kepemilikannya kepada warga desa lain. Padahal ada ketentuan yang melarang peralihan tanah tersebut khususnya kepada orang di luar desa. Kedua, penguasaan tanah khususnya dalam penentuan subyek yang ditunjuk oleh desa untuk mengolah sawah buruhan mulai didasarkan unsur-unsur subyektif desa misalnya tidak semata untuk petani tak bertanah namun juga dalam rangka pengerahan massa untuk keperluan politik. ${ }^{35}$ Penguasaan sawah buruhan mengalami perubahan dengan mulai dilakukannya peralihan melalui jual/sewa garap kepada pihak lain. ${ }^{36}$ Ketiga, terkait peruntukan atau penggunaannya, terlihat perubahan dalam komoditas pertanian yang ditanam yang awalnya tanaman pertanian dan palawija menjadi tanaman keras seperti jabon atau jati Belanda yang dinilai lebih menguntungkan dan tidak membutuhkan perawatan lebih. ${ }^{37}$

Distribusi tanah garapan dari tanah komunal desa pada masa kini dilakukan berdasar prinsip kesamarataan formal, padahal dahulu didasarkan pada prinsip kesamarataan substantif. Kesamarataan substantif berarti disesuaikan dengan kebutuhan dan kemampuan, sedangkan kesamarataan formal didorong oleh kesadaran tentang Hak Asasi Manusia (HAM) dengan prinsip sama rata bagi seluruh warga. Tiap garapan sama luas berdasarkan konsep persamaan hak atas tanah diantara para penggarap tanpa memandang alasan ekonomi misalnya besarnya tenaga kerja, kebutuhan atau kemampuan hasil yang dicapai. Keadaan ini bukan hasil perintah tuan tanah tetapi timbul karena hubungan pengelolaan tanah oleh desa sebagai persekutuan hukum.

Pola distribusi formal ini memiliki resiko pada tingkat kesejahteraan masyarakat desa yang ada. Tanah garapan seringkali belum mampu menjadi sumber kehidupan dan penghidupan yang

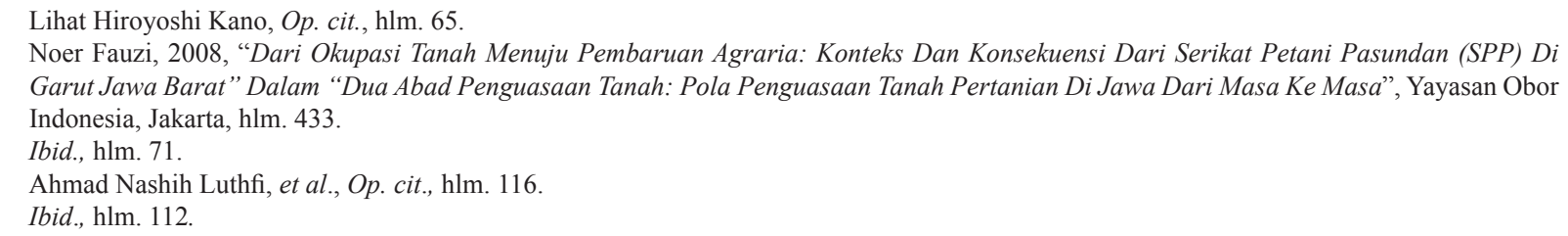


layak bagi penggarapnya, sehingga distribusi tanah yang ada juga menampakkan wujudnya sebagai distribusi kemiskinan bagi warga. Antropolog Amerika, Clifford Geertz $^{38}$ melihat adanya hubungan langsung antara cultuurstelsel dengan agricultural involution, suatu sistem produksi sawah yang melibatkan banyak orang. Sifatnya sangat menyerap tenaga kerja dan selalu dapat melibatkan semakin banyak orang tanpa penurunan produksi. Hal itu justru menimbulkan kemelaratan bersama dan akhirnya masing-masing memperoleh bagian yang makin kecil yang tidak mampu menopang kebutuhan hidup tiap orang.

Berbagai kelemahan dan kekurangan dalam pengakuan hak komunal, berfokus pada lemahnya pengakuan hukum yang mampu mewadahi fenomena yang ada. Penulis mencatat bahwa pada masa lalu, pengakuan atas eksistensi lembaga desa sebagai otoritas yang berwenang dalam mengatur keberadaan tanah adat di desa kuat. Subekti menyebutkan beberapa yurisprudensi mahkamah agung mengenai hukum adat terutama terkait adanya kewenangan desa dalam penguasaan tanah melalui hak gogolan dan pekulen, diantaranya: ${ }^{39}$ pertama, putusan Mahkamah Agung (MA) tanggal 21-6-1958 No. 149 K/Sip/1958 yang memutuskan bahwa Pengadilan Negeri tidak berkuasa merobah atau membatalkan putusan desa mengenai sawah pekulen, kedua putusan M.A. tanggal 10-10-1956 No.32K/Sip/1956yang menyatakan menuruthukum adat di desa Sukorejo, Kabupaten Lamongan, tanah gogol (bukan tanah yasan) hanya dapat dihaki atau dipinjam oleh orang-orang yang berdiam di dalam wilayah desa tersebut. Hal itu sudah selaras dengan sifat hak gogolan sebagai suatu hak yang bersumber pada hak ulayat desa.Hak tersebut hanya dapat diberikan kepada anggota-anggota masyarakat desa itu sendiri dan tidak kepada "orang luar". Putusan Pengadilan Negeri Lamongan yang dikuatkan oleh Mahkamah Agung sudah tepat, dan ketiga putusan M.A. tanggal 18-10-1958 No. 301 K/Sip/1958.
Penunjukan tanah pekulen adalah hak semata-mata dari rapat desa, yang diberikan oleh Hukum Adat. Pengadilan Negeri tidak berhak meninjau tentang benar tidaknya putusan rapat desa tersebut. Putusan rapat desa dalam perkara ini, dapat dipandang sebagai pelaksanaan dari hak penguasaan desa (doorpsbeschikkingsrecht), dari dulu dihormati oleh pengadilan, dalam arti tidak boleh dinilai lagi oleh pengadilan.

Alasan ini belum menjadi dasar yang cukup bagi pemerintah untuk secara tegas dan tepat melakukan pengaturan atas tanah pekulen atau gogol yang sifatnya bergilir ini termasuk memperkuat lembaga desa. Fakta menunjukkan khusus tanah pekulen dan gogol yang bergilir, ketentuan hukum yang ada masih menimbulkan konflik karena dianggap kurang tepat oleh masyarakat. Pengaturan hukum khusus mengenai kedua jenis tanah adat ini dapat kita lihat melalui ketentuan Pasal VII Ketentuan Konversi UUPA sebagai berikut:

(1) Hak gogolan, pekulen atau sanggan yang bersifat tetap yang ada pada mulai berlakunya Undang-undang ini menjadi hak milik tersebut pada Pasal 20 ayat (1).

(2) Hak gogolan, pekulen atau sanggan yang tidak bersifat tetap menjadi hak pakai tersebut pada Pasal 41 ayat (1) yang memberi wewenang dan kewajiban sebagai yang dipunyai oleh pemegang haknya pada mulai berlakunya Undang-undang ini.

(3) Jika ada keragu-raguan apakah sesuatu hak gogolan, pekulen atau sanggan bersifat tetap atau tidak tetap, maka Menteri Agrarialah yang memutuskan.

Pasal ini membagi hak pekulen/gogolan menurut sifatnya menjadi 2 yaitu tetap dan tidak tetap. Kriteria mengenai pekulen/ gogolan tetap diatur dalam Pasal 20 ayat (2) Peraturan Menteri Agraria No. 2 Tahun 1960 tentang Pelaksanaan 
Beberapa Ketentuan UUPA yaitu bahwa hak gogolan, sanggan atau pekulen bersifat tetap kalau para gogol terus menerus mempunyai tanah golongan yang sama atau jika meninggal dunia gogolnya itu jatuh pada warisnya tertentu. Pada ayat (4) jika ada perbedaan pendapat antara kepala inspeksi agraria dan Bupati Kepala Daerah tentang apakah sesuatu hak gogolan bersifat tetap atau tidak tetap, demikian juga jika desa yang bersangkutan berlainan pendapat dengan kedua pejabat tersebut maka soalnya dikemukakan lebih dahulu kepada Menteri Agraria untuk mendapat keputusan.

Pembagian jenis tanah gogolan tidak tetap diatur menurut Keputusan Bersama Menteri Negara Agraria dan Menteri Dalam Negeri Nomor 30/ DEPAG/1965.11/DDN/1965. Kriterianya terdiri dari 3 bentuk, yaitu matok sirah gilir galeng, gogol musiman, dan gogol gilir mati. Secara garis besar, prosedur teknis yang ditempuh dalam rangka konversi meliputi: Pertama, untuk menentukan apakah suatu hak gogolan/ pekulen adalah tetap atau bergilir diatur dalam Pasal 20 ayat (3) dan (4) Peraturan Menteri Agraria No. 2 Tahun 1960. Kedua, bupati/ kepala daerah tingkat II dan Kepala Inspeksi Agraria yang bersangkutan untuk di dalam waktu sesingkat-singkatnya menyelenggarakan penegasan konversi hak gogolan tetap yang ada didaerahnya menjadi hak milik dan hak gogolan tidak tetap dikonversi menjadi hak pakai yang tunduk pada ketentuan UUPA. Ketiga, setelah ada penegasan dari panitia landreform kecamatan/ panitia landreform kabupaten maka tanah bekas hak gogol tidak tetap (yang telah dikonversi menjadi hak pakai) diberikan dengan hak milik oleh kepala kantor wilayah BPN (saat ini menjadi Kementerian Agraria dan Tata Ruang/Badan Pertanahan Nasional), dan keempat untuk kemantapan maka keluar Keputusan Bersama Menteri Agraria Dan Menteri Dalam Negeri Nomor 30/DEPAG/1965. 11/ DDN/1965 tanggal 4 mei 1965 tentang Penegasan Konversi Menjadi Hak Pakai Dan Pemberian Hak Milik Atas Tanah Bekas Hak Gogolan Tidak Tetap. Keseluruhan proses konversi tersebut harus dimohon atas inisiatif pemegang hak sesuai ketentuan Peraturan Menteri Pertanian Dan Agraria No. 2 Tahun 1962 tentang Penegasan Konversi Dan Pendaftaran Bekas Hak Indonesia Atas Tanah.

Hak pekulen yang bersumber dari hukum adat baik masyarakat dengan nilai-nilai hukum adat yang masih kuat maupun telah memudar bahkan hilang, memilikiarti penting sebagai bentuk hak tanah. pada kedudukan sebagai hak tanah ini, hak pekulen memiliki sifat yang kuat sebagai turunan dari sifat hak bangsa dalam tata jenjang hak penguasaan atas tanah. pembentukan hukum nasional melalui UUPA mengharuskan adanya konversi dengan maksud tetap mengakui keberadaan hak lama untuk disesuaikan dengan hak atas tanah menurut UUPA. Secara historis dan filosofis tanah dihormati sebagai sebuah anugerah Tuhan sehingga mengandung unsur religius serta watak kebersamaan dalam sifat komunalistiknya. Kategorisasi/ pembagian jenis hak pekulen menjadi tetap dan bergilir dengan melihat penguasaan dan pemanfaatnya menjadi titik utama dalam menentukan konversinya. Sebagaimana disebutkan di depan bahwa hak pekulen tetap akan dikonversi menjadi hak milik. Secara historis dan filosofis hal ini sesuai dengan sifatnya penguasaannya yaitu tetap, tidak ada batasan waktu penguasaan, serta dapat diwariskan. Karakter perseorangan/ pribadi ini sesuai dengan sifat hak milik sebagai hak yang terkuat dan terpenuh yang dimiliki seseorang atas tanah. kejelasan dan kepastian akan subyek dan obyek hak terpenuhi secara tepat sehingga secara sosiologis juga mendapat legitimasi dari masyarakat sekitar. Hak pekulen bergilir menurut ketentuan konversi, akan diubah menjadi hak pakai. Secara yuridis normatif, sifat hak pekulen bergilir memang hanya disertai kewenangan untuk memakai/ menggarap tanah saja namun terbatas waktu dan tidak dapat diwariskan. Karakter penguasaan sementara ini menegaskan adanya pihak lain yang lebih memiliki hak penuh atas tanah yang ada. Konversi hak pekulen bergilir menjadi hak pakai terhadap penggarapnya yang terakhir kiranya telah sesuai dengan sisi filosofis, dan sosiologis yang dimiliki hak tersebut. Yang seringkali menjadi 
pertanyaan bahwa dalam proses konversi hak tersebut, mekanisme yang ditempuh adalah melalui pengajuan hak atas tanah terhadap tanah negara obyek land reform. Prosedur ini sebenarnya kurang tepat, mengingat bahwa konversi hak selayaknya menegaskan adanya pengakuan negara atas hak tanah yang lama dan menyesuaikannya dengan ketentuan jenis dan karakteristik hak tanah yang ada dalam hukum nasional. Bukan dengan memohon hak tanah yang menimbulkan kesan bahwa secara historis tanah yang dimohon tersebut merupakan tanah negara. Hal ini seolah-olah merancukan asal usul dan sumber hak tanah yang ada.

Problematika konversi hak pekulen bergilir ini muncul akibat ketidakjelasan subyek tanah asalnya. Secara historis, diketahui bahwa tanah pekulen bergilir ini umumnya berada dalam penguasaan dan pemilikan desa dalam rangka mendorong produkstivitas pertanian dan pengaturan tenaga kerja. Konversi hak pekulen bergilir menjadi hak pakai memunculkan pertanyaan baru, yaitu hak pakai di atas tanah apa? UUPA secara detail tidak menyebutkan sumber tanah yang dilekatinya, namun dalam peraturan pelaksanaannya hak yang ada diterbitkan di atas tanah negara. Padahal kenyataannya, secara de jure dan de facto tanah tersebut berada dalam pemilikan dan penguasaan desa yang kemudian mendelegasikan hak penguasaan dan pemanfaatannya kepada petani penggarap. Hal ini menjadi sulit diterjemahkan mengingat belum diakuinya lembaga desa sebagai subyek hak serta terbatasnya pengaturan tentang tanah komunal/ tanah bersama.

Diskursus tentang tanah komunal dalam pengaturan hukum secara eksplisit dapat ditemui dalam Keputusan Menteri Agraria dan Tata Ruang/ Badan Pertanahan Nasional No. 9 Tahun 2015 tentang Tata Cara Penetapan Hak Komunal Atas Tanah Masyarakat Hukum Adat dan Masyarakat yang berada dalam Kawasan Tertentu yang diganti dengan Peraturan Menteri Agraria dan Tata Ruang/ Kepala Badan Pertanahan Nasional Nomor 10 Tahun
2016 tentang Tata Cara Penetapan Hak Komunal atas Tanah Masyarakat Hukum Adat dan Masyarakat Yang Berada Dalam Kawasan Tertentu. Rumusan aturan yang ada memberikan batasan tentang hak komunal dengan kriteria pertama, hanya dimiliki oleh masyarakat adat, kedua seolah-olah merupakan hak atas tanah karena dilengkapi dengan alat bukti berupa sertifikat sementara UUPA tidak mengatur hak komunal sebagai suatu hak atas tanah, ketiga pengaturan tentang hak komunal hanya terbatas pada wilayah kawasan tertentu yaitu hutan dan perkebunan. Ketentuan ini juga telah menghapus keberadaan hak ulayat yang diatur dalam Pasal 5 UUPA. Maria SW Sumardjono menekankan bahwa hak komunal tidak dapat dipersamakan dengan hak ulayat karena adanya perbedaan karakteristik dimensi publik yang tidak dimiliki hak komunal. ${ }^{40}$ Padahal pada kenyataannya dalam masyarakat masih banyak ditemui hak komunal/ milik bersama yang belum diakomodir ketentuan hukum.

Peluang dan kemungkinan pengaturan yang lebih komprehensif sangat terbuka. Hal ini dibuktikan dengan fenomena yang terjadi di Sidoarjo. Meskipun tanah gogol gilir telah dapat disertipikatkan dengan sertipikat hak milik karena dianggap alas hak yang ada adalah gogol tetap, namun dalam praktek penguasaan dan penggunaannya masih tetap dilakukan secara bergilir oleh masyarakat. Kondisi lain ditunjukkan di Ngandagan Purworejo yang menghasilkan kebijakan "landreform lokal" melalui pengambilan sebagain tanah pekulen tetap untuk dijadikan tanah komunal desa dengan penguasaan secara bergilir bagi masyarakat.

Pengaturan sumber daya pada tingkat lokal memberikan banyak kemungkinan kemanfaatan sekaligus ketepatan pada aras hulu. Perkembangan pengaturan tentang otonomi desa sebagai satuan pemerintahan terkecil diperkuat dengan lahirnya UU No. 6 Tahun 2014 tentang Desa. UU ini tidak semata-mata menempatkan desa dalam kerangka otonomi daerah dan ketatanegaraan Indonesia saja.

40 Maria SW Sumardjono, "Ihwal Hak Komunal Atas Tanah “, Harian Kompas, 6 Juli 2015. 
UU ini diharapkan mampu menjadi pintu masuk bagi pembangunan dan penguatan perekonomian rakyat. Pada tingkat tertentu, dengan bekal UU Desa yang telah ada, desa memiliki otoritas melakukan reforma agraria skala lokal dan penguasaan lahan bagi kemaslahatan bersama. ${ }^{41} \mathrm{Hal}$ ini sesuai dengan logika bahwa desa merupakan sumber penghidupan sebagai tempat tinggal bagi sebagaian besar masyarakat dan sekaligus menjadi tempat beragam faktor produksi modal seperti sumber daya khususnya tanah dan tenaga kerja. Modal yang dimiliki tersebut membutuhkan saluran dan sistem yang baik dengan tetap mempertahankan kearifan lokal yang ada sehingga mampu memberikan manfaat bagi kesejahteraan masyarakat desa khususnya dan negara umumnya.

Yurisprudensi putusan Mahkamah Agung tanggal 18-10-1958 No. 301 K/Sip/1958 menyebutkan adanya hak penguasaan desa (doorsbeschikkingsrecht) tentang putusan desa perihal penunjukan tanah pekulen. Hal ini menunjukkan adanya kewenangan dan legitimasi yang dimiliki oleh desa untuk menjalankan otonominya dalam mengatur sumberdaya tanahnya. Myrna Savitri menawarkan opsi bagi bentuk hak komunal:

Satu, tanah komunal itu membentuk sistem kepemilikan berlapis dimana kepemilikan individual/keluarga/kelompok kecil dimungkinkan ada di dalamnya. Dua, ketika berhadapan dengan pihak ketiga, maka tanah komunal itu dilihat sebagai kesatuan properti yang utuh dari anggota komunitas. Properti ini punya sifat khusus yang tidak bisa dialihkan kepada pihak luar secara permanen termasuk penggunaannya sebagai agunan akad kredit yang beresiko beralih kepada pihak luar. Tiga, sebagai hak properti yang utuh maka tanah-tanah komunal tidak dapat disamakan dengan tanah publik/tanah negara melainkan tanah rakyat yang dikuasai dengan hak yang jelas yang diakui dan dilindungi oleh negara. Empat, untuk mendukung perlindungan terhadap tanah komunal maka komunitas lokal perlu diperlakukan sebagai subyek hukum sama halnya dengan perorangan atau badan hukum. ${ }^{42}$

Berdasarkan hal tersebut, berikut skema hak atas tanah yang dapat dipergunakan:

Tabel 3. Skema Pengaturan Hak Tanah Bagi Tanah Pekulen

\begin{tabular}{|c|c|c|}
\hline No. & Jenis Hak & Keterangan \\
\hline 1. & Hak Bersama & $\begin{array}{l}\text { Sertipikat/ kepemilikan atas bidang tanah oleh beberapa orang. Namun kewenangan desa } \\
\text { menjadi hilang karena tanah dapat dengan mudah dialihkan kepada orang di luar desa } \\
\text { dengan kesepakatan para pemilik saja. }\end{array}$ \\
\hline 2. & Hak Pakai & $\begin{array}{l}\text { Penggarap terakhir dapat diberikan hak pakai untuk jangka waktu tertentu dan } \\
\text { selanjutnya tanah dapat digilirkan dengan hak pakai kepada pihak lain. Namun status } \\
\text { utama atas tanah ini apa? Sedangkan desa belum merupakan subjek hak. }\end{array}$ \\
\hline 3. & Hak Pengelolaan & $\begin{array}{l}\text { Bersifat publik, dimana tanah adalah tanah negara dan dapat ditarik kembali. } \\
\text { Dimungkinkan dalam konteks HPL komunitas berlaku atas tanah komunitas sebagai } \\
\text { bentuk pengakuan eksistensinya. Kewenangan desa dalam mengatur peruntukan dan } \\
\text { penggunaan tanah dan sumber daya termasuk memberikan hak-hak pemanfaatan tanah } \\
\text { kepada anggota komunitas dapat dilaksanakan dan memberi kepastian hukum. }\end{array}$ \\
\hline
\end{tabular}

Sumber: Myrna Safitri, ${ }^{43} 2012$.

\section{Penutup}

Tanah pekulen merupakan bentuk hak atas tanah yang yang bersumber dari hukum adat. Hukum agraria nasional yang direpresentasikan melalui ketentuan UUPA telah diproyeksikan untuk menghapuskan adanya dualisme hukum agraria yang ada di Indonesia. Namun, ketentuan konversi yang ditetapkan oleh pemerintah ternyata

\footnotetext{
41 Ahmad Erani Yustika, "Desa, Tanah, dan Pasar", Harian Kompas, 18 Februari 2016.

42 Myrna Safitri, 2012, Mempertanyakan Posisi Sistem Tenurial Lokal Dalam Pembaruan Agraria Di Indonesia Dalam Pembentukan Kebijakan Reforma Agraria 2006-2007 Bunga Rampai Perdebatan, STPN Press dan Sajogyo Institute, Yogyakarta, hlm. 77-79.

43 Myrna Safitri, Ibid.
} 
belum mampu sepenuhnya mengakomodasi hak tanah pekulen khususnya yang bersifat bergilir serta memiliki karakteristik komunal. Berdasarkan ketentuan UUPA hak pekulen tetap akan dikonversi menjadi hak milik sedangkan hak pekulen bergilir menjadi hak pakai. Secara historis, filosofis, dan sosiologis, ketentuan yuridis ini tepat untuk hak pekulen tetap namun membutuhkan kajian lebih lanjut terkait hak pekulen bergilir. Struktur agraria hak pekulen bergilir dapat dilihat dalam karakter, yaitu pemilikannya bersifat bersama dari seluruh warga desa, serta penguasaan dan pemanfaatannya dapat dilakukan secara perseorangan oleh warga desa atas keputusan desa.

Pengaturan tanah pekulen dalam struktur hukum agraria Indonesia dapat dilihat dalam asas serta norma dan kaidah hukum UUPA. Hak pekulen memiliki karakter komunalistik religius serta dekat dengan fungsi sosial atas tanah yang diamanatkan UUPA. Kaidah dan norma yang mengaturnya secara tegas termuat dalam ketentuan konversi UUPA yang menempatkannya sebagai salah satu hak atas tanah meskipun belum sepenuhnya tepat mengakomodir. Selayaknya pengaturan tentang konversi hak pekulen bergilir ini mengakomodir nilai-nilai dalam masyarakat sebagai lingkungan hidupnya. Watak komunal yang dimiliki hak pekulen bergilir belum mampu diwadahi dalam konsep hak komunal negara yang membatasi diri pada masyarakat adat, serta hanya ada di wilayah hutan dan perkebunan. Hak pekulen bergilir patut dimasukkan dalam kategori hak komunal dalam lingkungan desa yang kental dengan solidaritas/ kebersamaan, nilai budaya/ tradisi, serta legitimasi kewenangannya dalam kerangka otonomi desa.

\section{DAFTAR PUSTAKA}

\section{A. Buku}

Aass, Svein, 2008, Relevansi Teori Makro Chayanov dalam Dua Abad Penguasaan Tanah: Pola Penguasaan Tanah Pertanian Di Jawa Dari Masa Ke Masa, Yayasan Obor Indonesia, Jakarta.

Billah, M., et al., 2008, Sistem Pemilikan Tanah dan Masyarakat Desa di Jawa Pada Abad XIX dalam "Dua Abad Penguasaan Tanah: Pola Penguasaan Tanah Pertanian Di Jawa Dari Masa Ke Masa”, Yayasan Obor Indonesia, Jakarta.

Cahyati, Devy Dhian, 2014, Konflik Agraria Di Urutsewu, Pendekatan Ekologi Politik, STPN Press, Yogyakarta.

Fauzi, Noer, 2008, "Dari Okupasi Tanah Menuju Pembaruan Agraria: Konteks Dan Konsekuensi Dari Serikat Petani Pasundan (SPP) Di Garut Jawa Barat” Dalam "Dua Abad Penguasaan Tanah: Pola Penguasaan Tanah Pertanian Di Jawa Dari Masa Ke Masa", Yayasan Obor Indonesia, Jakarta.

Geertz, C., 1963, Agricultural Involution: The
Process Of Ecological Change In Indonesia, University Of California Press, California.

Harsono, Boedi, 2003, Hukum Agraria Indonesia, Sejarah Pembentukan Undang-undang Pokok Agraria, Isi, dan Pelaksanaannya, Djambatan, Jakarta.

Kano, Hiroyoshi, 2008, Sistem Pemilikan Tanah Dan Masyarakat Desa Di Jawa Pada Abad XIX Dalam "Dua Abad Penguasaan Tanah: Pola Penguasaan Tanah Pertanian Di Jawa Dari Masa Ke Masa," Yayasan Obor Indonesia, Jakarta.

Luthfi, Ahmad Nashih, et al., 2013, Kondisi Dan Perubahan Agraria Desa Ngandagan Di Jawa Tengah Dulu Dan Sekarang, STPN Press, Yogyakarta.

Safitri, Myrna, 2012, Mempertanyakan Posisi Sistem Tenurial Lokal Dalam Pembaruan Agraria Di Indonesia Dalam Pembentukan Kebijakan Reforma Agraria 2006-2007 Bunga Rampai Perdebatan, STPN Press dan Sajogyo Institute, Yogyakarta.

Setiawati, Nur Aini, 2011, Dari Tanah Sultan 
Menuju Tanah Rakyat: Pola Pemilikan, Warman, Kurnia, 2006, Ganggam Bauntuak Penguasaan, Dan Sengketa Tanah Di Kota Menjadi Hak Milik, Penyimpangan Konversi Yogyakarta Setelah Reorganisasi 1917, STPN Press dan Sains, Yogyakarta. Hak Tanah di Sumatera Barat, Andalas University Press, Padang.

Shohibuddin, Moh. dan Luthfi, Ahmad Nashih, 2010, Land Reform Lokal Ala Ngandagan, Inovasi Sistem Tenurial Adat di Sebuah Desa Jawa, 1947-1964, STPN Press dan SAINS, Yogyakarta.

Sihombing, BF., 2005, Evolusi Kebijakan Pertanahan Dalam Hukum Tanah Indonesia, Toko Gunung Agung, Jakarta.

Subekti, 1990, Hukum Adat Indonesia Dalam Yurisprudensi Mahkamah Agung, Cetakan ke-4, Alumni, Bandung.

Suhartono, 1991, Apanage dan Bekel, Tiara Wacana, Yogyakarta.

Vollenhoven, Cornelis Van, 2013, Orang Indonesia

\section{B. Artikel Koran}

Sumardjono, Maria SW, "Ihwal Hak Komunal Atas Tanah “, Harian Kompas, 6 Juli 2015.

Yustika, Ahmad Erani, "Desa, Tanah, dan Pasar", Harian Kompas, 18 Februari 2016.

dan Tanahnya, STPN Press, Yogyakarta. 